Clinical responses observed in patients treated with BRAF inhibitors do not support the suggestion of intra-patient BRAF heterogeneity as all metastases have a uniform initial metabolic response to BRAF inhibition assessed using FDG-PET imaging (McArthur et al, 2012), and all resistant lesions resected from patients still contain mutant BRAF (McArthur et al, 2011; Poulikakos et al, 2011; Van Allen et al, 2013).

Further clinical studies are required to examine the issue of intra-patient discordance of $B R A F$. Carefully assigning primary melanomas as culprit lesions, and using accurate $B R A F$ testing methods with adequate tumour cell content would be the requirements to underpin the data.

\section{ACKNOWLEDGEMENTS}

This work is supported by Program Grant 633004 of the National Health and Medical Research Council of Australia (NHMRC), Translational Research Program Grant 10/TPG/1-02 of the Cancer Institute NSW. GVL and RAS are funded by the Cancer Institute New South Wales and NHMRC Fellowship programmes. The funding bodies had no role in the opinions expressed in the letter.

\section{CONFLICT OF INTEREST}

AMM has received honoraria from Roche and travel support from Roche and GlaxoSmithKline (GSK). JSW declares no conflict of interest. GVL has been a consultant for Roche, Bristol-Myers Squibb, GSK and Novartis, and has received honoraria and travel support from Roche. RAS has been a consultant for Roche and GSK, and has received honoraria from Abbott Molecular.

\section{REFERENCES}

Boursault L, Haddad V, Vergier B, Cappellen D, Verdon S, Bellocq JP, Jouary T, Merlio JP (2013) Tumor homogeneity between primary and metastatic sites for BRAF status in metastatic melanoma determined by immunohistochemical and molecular testing. PLoS One 8(8): e70826.

Colombino M, Capone M, Lissia A, Cossu A, Rubino C, De Giorgi V, Massi D, Fonsatti E, Staibano S, Nappi O, Pagani E, Casula M, Manca A, Sini M, Franco R, Botti G, Caraco C, Mozzillo N, Ascierto PA, Palmieri G (2012) BRAF/NRAS mutation frequencies among primary tumors and metastases in patients with melanoma. J Clin Oncol 30(20): 2522-2529.
Heinzerling L, Baiter M, Kuhnapfel S, Schuler G, Keikavoussi P, Agaimy A, Kiesewetter F, Hartmann A, Schneider-Stock R (2013) Mutation landscape in melanoma patients clinical implications of heterogeneity of BRAF mutations. Br J Cancer 109: 2833-2841.

Long GV, Wilmott JS, Capper D, Preusser M, Zhang YE, Thompson JF, Kefford RF, von Deimling A, Scolyer RA (2013) Immunohistochemistry is highly sensitive and specific for the detection of V600E BRAF mutation in melanoma. Am J Surg Pathol 37(1): 61-65.

McArthur GA, Puzanov I, Amaravadi R, Ribas A, Chapman P, Kim KB, Sosman JA, Lee RJ, Nolop K, Flaherty KT, Callahan J, Hicks RJ (2012) Marked, homogeneous, and early $[18 \mathrm{~F}]$ fluorodeoxyglucose-positron emission tomography responses to vemurafenib in BRAF-mutant advanced melanoma. J Clin Oncol 30(14): 1628-1634.

McArthur GA, Ribas A, Chapman PB, Flaherty KT, Kim KB, Puzanov I, Nathanson KL, Lee RJ, Koehler A, Spleiss O, Bollag G, Wu W, Trunzer K, Sosman JA (2011) Molecular analyses from a phase I trial of vemurafenib to study mechanism of action (MOA) and resistance in repeated biopsies from BRAF mutationpositive metastatic melanoma patients (pts). J Clin Oncol 29(Suppl 15): abstract 8502 .

Menzies AM, Lum T, Wilmott JS, Hyman J, Kefford RF, Thompson JF, O’Toole S, Long GV, Scolyer RA (2013) Intrapatient homogeneity of BRAFV600E expression in melanoma. Am J Surg Pathol; e-pub ahead of print 12 December 2013; doi:10.1097/PAS.0000000000000136.

Murali R, Brown PT, Kefford RF, Scolyer RA, Thompson JF, Atkins MB, Long GV (2012) Number of primary melanomas is an independent predictor of survival in patients with metastatic melanoma. Cancer 118(18): 4519-4529.

Poulikakos PI, Persaud Y, Janakiraman M, Kong X, Ng C, Moriceau G, Shi H, Atefi M, Titz B, Gabay MT, Salton M, Dahlman KB, Tadi M, Wargo JA, Flaherty KT, Kelley MC, Misteli T, Chapman PB, Sosman JA, Graeber TG, Ribas A, Lo RS, Rosen N, Solit DB (2011) RAF inhibitor resistance is mediated by dimerization of aberrantly spliced BRAF(V600E). Nature 480(7377): 387-390.

Saint-Jean M, Quéreux G, Nguyen J-M, Peuvrel L, Brocard A, Vallée A Knol A-C, Khammari A, Denis MG, Dréno B (2014) Is a single BRAF wild-type test sufficient to exclude melanoma patients from vemurafenib therapy? J Invest Dermatol 13(5): 1468-1470.

Van Allen EM, Wagle N, Sucker A, Treacy DI, Johannessen CM, Goetz EM, Place CS, Taylor-Weiner A, Whittaker S, Kryukov GV, Hodis E, Rosenberg M, McKenna A, Cibulskis K, Farlow D, Zimmer L, Hillen U, Gutzmer R, Goldinger SM, Ugurel S, Gogas HJ, Egberts F, Berking C, Trefzer U, Loquai C, Weide B, Hassel JC, Gabriel SB, Carter SL, Getz G, Garraway LA, Schadendorf D (2013) The genetic landscape of clinical resistance to RAF inhibition in metastatic melanoma. Cancer Discov; e-pub ahead of print 22 November 2013.

*Correspondence: Professor RA Scolyer; E-mail: richard.scolyer@sswahs.nsw.gov.au

Published online 24 December 2013

(c) 2014 Cancer Research UK. All rights reserved 0007-0920/14

This work is licensed under the Creative Commons

\title{
Reply: Intra-patient heterogeneity of BRAF mutation status: fact or fiction?
}

\author{
L Heinzerling $^{*}, 1$, G Schuler ${ }^{1}$, A Hartmann ${ }^{2}$ and R Schneider-Stock ${ }^{2,3}$ \\ ${ }^{1}$ Department of Dermatology, University Hospital Erlangen, 91054 Erlangen, Germany; ${ }^{2}$ Department of Pathology, University of Erlangen-Nürnberg, \\ 91054 Erlangen, Germany and ${ }^{3}$ Experimental Tumor Pathology, Department of Pathology, University of Erlangen-Nürnberg, 91054 Erlangen, Germany
}

We thank Menzies et al (2014b) for their interest in our work and their detailed and informative remarks that extend what we discussed in our paper. They are concerned that our findings of an unexpected high percentage of heterogeneity reflect methodical problems of mutation detection rather than tumour biology. In contrast, our main worry is that acknowledged and widely used diagnostic techniques could exclude a significant percentage of patients from BRAF inhibitor therapy despite the presence of mutated metastases. Indeed, our study was initiated because we could not believe in the intrapatient heterogeneity even though we like other groups (Houben et al, 2004) were occasionally getting divergent results when retesting new metastases from patients. We will try to explain in our reply why we do not believe that there are 'easy' explanations such as lack of sensitivity, low tumour content in samples studied and higher sensitivity of immunohistochemical analyses compared with direct mutation detection.

We are aware that our findings could be due to sensitivity of our testing methods. The suggested approach of immunohistochemistry (IHC), however, will not suffice to detect BRAF mutations. Indeed a substantial patient population will be missed as we and others have shown that rare BRAF mutations are not (V600K, V600D, L597S, V600DK601del, V600R) or not always detected by IHC (Skorokhod et al, 2012; Heinzerling et al, 2013).
Similarly, the COBAS test does not reliably detect rare mutations (Heinzerling et al, 2013). Rare mutations have been described in up to $20 \%$ of BRAF-mutated patients by your group and others (Beadling et al, 2011; Long et al, 2011; Dahlman et al, 2012) and it is crucial to detect them as these patients respond to therapy with BRAF inhibitor (Chapman et al, 2011; Klein et al, 2013). Thus, even though possibly the intrapatient heterogeneity might be lower in the published IHC study by Menzies et al (2014a) using IHC as only detection technique would exclude patients with actionable mutations from effective treatment with a BRAF inhibitor. Furthermore, discordance rates of course also depend on the number of samples tested. And even the study with lowest rates of heterogeneity only using paired samples of primary tumour and one metastatic lesion found heterogeneity in some patients with concordant results in $90.9 \%$ (Boursault et al, 2013). It is likely that the rate of heterogeneity is higher when testing more samples per patient (up to 13 in our studies) and as shown by Colombino depends on the type of metastases with highest rates of $24 \%$ heterogeneity for skin metastases (overall discordance rate: $15 \%$; Colombino et al, 2012). Furthermore, in our article we show intratumoural heterogeneity of the immunohistochemical BRAFV600 staining, a finding that has been confirmed by other groups using molecular methods (Lin et al, 2011; Yancovitz et al, 2012). In addition, 
heterogeneity has been detected not only between primary tumour and metastases, which could be explained by multiple primaries or occult primaries, but also between metastases, and this explanation certainly could not account for the rates of discordance seen. In our hands, we routinely use IHC as an important additional method for BRAF mutation screening.

Test sensitivity has been described differentially for the various testing methods (Lade-Keller et al, 2013). It was shown, however, that in samples with at least $10 \%$ tumour cell content $100 \%$ consensus was achieved between five different methods: the COBAS test, Sanger sequencing, pyrosequencing, TaqMan-based allele-specific PCR and competitive amplification of differentially melting amplicons. The sensitivity of pyrosequencing has previously been tested using DNA dilutions mixing heterogenous V600E tumour with normal lymphocytes and found to be highly accurate even if tumour content was only $20 \%$ (Spittle et al, 2007). In this study we have microdissected the tumour area from the tissue sections that yielded a tumour content of $>75 \%$ as described previously (Heinzerling et al, 2013). Accounting for the heterozygous presence of the mutated gene in most tumours (Sigalotti et al, 2011) and the presence of stromal elements this is well above the detection limit.

In the clinical context, the majority of patients respond to BRAF inhibitors and mostly, metastases uniformly regress and then progress again once resistance is acquired. We even saw this pattern in one discordant patient (patient \#3). However, besides the specific inhibitory effect of BRAF inhibitors on BRAF V600-mutated cells, relevant immunological effects of BRAF inhibitors are increasingly becoming apparent. A reversion of immunosuppression by vemurafenib with a decrease of immunosuppressant myeloid-derived suppressor cells in response to treatment has been reported (Schilling et al, 2013) as well as a restoration of compromised dendritic cell function (Ott et al, 2013). Similarly, an analysis of lymphocyte counts in peripheral blood has shown a differential influence of vemurafenib and dabrafenib (Schilling et al, 2014). Furthermore, in vitro treatment with BRAF inhibitors lead to an increased expression of melanocyte differentiation antigens conferring enhanced antigen-specific recognition by cytotoxic $\mathrm{T}$ lymphocytes without compromising lymphocyte function (Boni et al, 2010). Thus, potentially the response to BRAF inhibitors could be partially mediated immunologically, which is backed by the finding of a marked T-cell infiltration induced by BRAF inhibitor therapy in vivo in melanoma patients (Wilmott et al, 2012). This could implicate that even wild-type metastases could respond to therapy with BRAF inhibitors. However, these hypotheses still need to be further evaluated.

Until now, mutation results from different tumour samples of one patient may differ for various reasons that could lead to exclusion of the patient from effective BRAF therapy. As stated in the conclusion of our paper and in the letter of Menzies et al (2014b), the role of heterogeneity in testing needs to be further investigated because it has profound clinical consequences; and as shown by our publication, it quite surprisingly relates to a substantial subset of patients tested by acknowledged diagnostic methods.

\section{REFERENCES}

Beadling C, Heinrich MC, Warrick A, Forbes EM, Nelson D,

Justusson E, Levine J, Neff TL, Patterson J, Presnell A, McKinley A, Winter LJ, Dewey C, Harlow A, Barney O, Druker BJ, Schuff KG, Corless CL (2011) Multiplex mutation screening by mass spectrometry evaluation of 820 cases from a personalized cancer medicine registry. J Mol Diagn 13(5): 504-513.

Boni A, Cogdill AP, Dang P, Udayakumar D, Njauw CN, Sloss CM, Ferrone CR Flaherty KT, Lawrence DP, Fisher DE, Tsao H, Wargo JA (2010) Selective BRAFV600E inhibition enhances T-cell recognition of melanoma without affecting lymphocyte function. Cancer Res 70(13): 5213-5219.

Boursault L, Haddad V, Vergier B, Cappellen D, Verdon S, Bellocq JP, Jouary T, Merlio JP (2013) Tumor homogeneity between primary and metastatic sites for BRAF status in metastatic melanoma determined by immunohistochemical and molecular testing. PLoS One 8(8): e70826.
Chapman PB, Hauschild A, Robert C, Haanen JB, Ascierto P, Larkin J, Dummer R, Garbe C, Testori A, Maio M, Hogg D, Lorigan P, Lebbe C, Jouary T,

Schadendorf D, Ribas A, O’Day SJ, Sosman JA, Kirkwood JM, Eggermont AM, Dreno B, Nolop K, Li J, Nelson B, Hou J, Lee RJ, Flaherty KT, McArthur GA (2011) Improved survival with vemurafenib in melanoma with BRAF V600E mutation. N Engl J Med 364(26): 2507-2516.

Colombino M, Capone M, Lissia A, Cossu A, Rubino C, De Giorgi V, Massi D, Fonsatti E, Staibano S, Nappi O, Pagani E, Casula M, Manca A, Sini M, Franco R, Botti G, Caracò C, Mozzillo N, Ascierto PA, Palmieri G (2012) BRAF/NRAS mutation frequencies among primary tumors and metastases in patients with melanoma. J Clin Oncol 30(20): 2522-2529.

Dahlman KB, Xia J, Hutchinson K, Ng C, Hucks D, Jia P, Atefi M, Su Z, Branch S, Lyle PL, Hicks DJ, Bozon V, Glaspy JA, Rosen N, Solit DB, Netterville JL, Vnencak-Jones CL, Sosman JA, Ribas A, Zhao Z, Pao W (2012) BRAF(L597) mutations in melanoma are associated with sensitivity to MEK inhibitors. Cancer Discov 2(9): 791-797.

Heinzerling L, Kühnapfel S, Meckbach D, Baiter M, Kaempgen E, Keikavoussi P, Schuler G, Agaimy A, Bauer J, Hartmann A, Kiesewetter F, Schneider-Stock R (2013) Rare BRAF mutations in melanoma patients-implications for molecular testing in clinical practice. Br J Cancer 108(10): 2164-2171.

Houben R, Becker JC, Kappel A, Terheyden P, Brocker EB, Goetz R, Rapp UR (2004) Constitutive activation of the Ras-Raf signaling pathway in metastatic melanoma is associated with poor prognosis. J Carcinog 3(1): 6 .

Klein O, Clements A, Menzies AM, O’Toole S, Kefford RF, Long GV (2013) BRAF inhibitor activity in V600R metastatic melanoma. Eur J Cancer. 49(7): 1797-1798.

Lade-Keller J, Rømer KM, Guldberg P, Riber-Hansen R, Hansen LL, Steiniche T, Hager H, Kristensen LS (2013) Evaluation of BRAF mutation testing methodologies in formalin-fixed, paraffin-embedded cutaneous melanomas. J Mol Diagn 15(1): $70-80$.

Lin J, Goto Y, Murata H, Sakaizawa K, Uchiyama A, Saida T, Takata M (2011) Polyclonality of BRAF mutations in primary melanoma and the selection of mutant alleles during progression. Br J Cancer 104(3): 464-468.

Long GV, Menzies AM, Nagrial AM, Haydu LE, Hamilton AL, Mann GJ, Hughes TM, Thompson JF, Scolyer RA, Kefford RF (2011) Prognostic and clinicopathologic associations of oncogenic BRAF in metastatic melanoma. J Clin Oncol 29(10): 1239-1246.

Menzies AM, Lum T, Wilmott JS, Hyman J, Kefford RF, Thompson JF, O'Toole S, Long GV, Scolyer RA (2014a) Intrapatient homogeneity of BRAFV600E expression in melanoma. Am J Surg Pathol 38(3): 377-382.

Menzies AM, Wilmott JH, Long GV, Scolyer RA (2014b) Intra-patient heterogeneity of BRAF mutation status: fact of fiction? Br J Cancer; e-pub ahead of print 24 December 2013; doi: 10.1038/bjc.2013.796

Ott PA, Henry T, Baranda SJ, Frleta D, Manches O, Bogunovic D, Bhardwaj N (2013) Inhibition of both BRAF and MEK in BRAF(V600E) mutant melanoma restores compromised dendritic cell (DC) function while having differential direct effects on DC properties. Cancer Immunol Immunother 62(4): 811-822.

Schilling B, Sondermann W, Zhao F, Griewank KG, Livingstone E, Sucker A, Zelba H, Weide B, Trefzer U, Wilhelm T, Loquai C, Berking C, Hassel J, Kähler KC, Utikal J, Al Ghazal P, Gutzmer R, Goldinger SM, Zimmer L, Paschen A, Hillen U, Schadendorf D. DeCOG (2014) Differential influence of vemurafenib and dabrafenib on patients' lymphocytes despite similar clinical efficacy in melanoma. Ann Oncol 25(3): 747-753.

Schilling B, Sucker A, Griewank K, Zhao F, Weide B, Görgens A, Giebel B, Schadendorf D, Paschen A (2013) Vemurafenib reverses immunosuppression by myeloid derived suppressor cells. Int J Cancer 133(7): 1653-1663.

Sigalotti L, Fratta E, Parisi G, Coral S, Maio M (2011) Stability of BRAF V600E mutation in metastatic melanoma: new insights for therapeutic success? Br J Cancer 105(2): 327-328.

Skorokhod A, Capper D, von DA, Enk A, Helmbold P (2012) Detection of BRAF V600E mutations in skin metastases of malignant melanoma by monoclonal antibody VE1. I Am Acad Dermatol 67(3): 488-491.

Spittle C, Ward MR, Nathanson KL, Gimotty PA, Rappaport E, Brose MS, Medina A, Letrero R, Herlyn M, Edwards RH (2007) Application of a BRAF pyrosequencing assay for mutation detection and copy number analysis in malignant melanoma. J Mol Diagn 9(4): 464-471.

Wilmott JS, Long GV, Howle JR, Haydu LE, Sharma RN, Thompson JF, Kefford RF, Hersey P, Scolyer RA (2012) Selective BRAF inhibitors induce marked T-cell infiltration into human metastatic melanoma. Clin Cancer Res 18(5): 1386-1394.

Yancovitz M, Litterman A, Yoon J, Ng E, Shapiro RL, Berman RS, Pavlick AC, Darvishian F, Christos P, Mazumdar M, Osman I, Polsky D (2012) Intra- and inter-tumor heterogeneity of BRAF(V600E))mutations in primary and metastatic melanoma. PLoS One 7(1): e29336.

*Correspondence: Professor L Heinzerling; E-mail: lucie.heinzerling@uk-erlangen.de

Published online 15 May 2014

(c) 2014 Cancer Research UK. All rights reserved 0007-0920/14

This work is licensed under the Creative Commons 